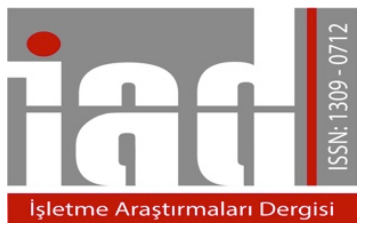

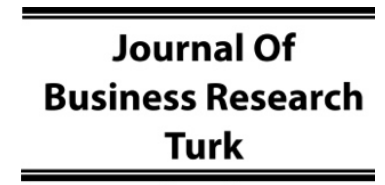

www.isarder.org

\title{
The Examination of the Relationship between Employees' Empowerment Perceptions and Their Organizational Commitments in Hotel Operations
}

\author{
İrfan Yazıcıŏglu \\ Gazi University \\ Faculty of Tourism \\ Ankara, Turkey \\ irfanyaz@gazi.edu.tr
}

\author{
Ersan EROL \\ Eskişehir Osman Gazi University \\ Faculty of Tourism \\ Eskişehir, Turkey \\ ersane@ogu.edu.tr
}

\begin{abstract}
The main goal of this study is to research the relationship between employees' empowerment perceptions and their organizational commitments in accommodation operations. The second goal of the study is to examine the differentiation of empowerment perception and organizational commitment in term of some demographic variables. In this scope, a case study was applied to 410 workers selected randomly from 4216 workers in 16 hotels in Ankara-Turkey. A questionnaire was used to collect data from respondents. All data were analyzed by using regression, correlation, $t$, and Anova statistical tests. According to the statistical tests, a significant relationship was found between empowerment of employees and organizational commitment. Also, the level of the relationship was calculated as $49.8 \%$.
\end{abstract}

Keywords: Employee empowerment and organizational commitment

\section{Introduction}

Today, rapid change and transformation in information systems and technology has been experienced. This change and transformation make the markets global, which aggravated the competition. To adopt new management approaches and practices have been made mandatory for business by global competitiveness. These approaches and practices are also called modern or contemporary management approaches. One of them is employee empowerment approache. The employee empowerment approach aims to create self-reliant, skilled and expertise employees who can respond the customers' requests quickly. It should be taken into account to tackle the problems that are faced by organizationand to different than competitors to achieve competitive advantages. (Koçel, 2010:409-410).

In the late 1970s and early 1980s, the concept of employee empowerment began to gain importance with quality circles, quality of work life and total quality of management studies. The concept was stated in literature by Harrison and Kanter (1983), Bennis and Naus (1985), Burke and Neilsen (1986), Block (1987 and House (1988), but concept did not stated accurately what it means in the first studies (Doğan, 2003: 6). In historical development stages of employee empowerment concept, it is 
defined in different ways in accordance with researchers' aims. As a concept, employee empowerment can be defined as helping each other, sharing, nurturing, improve the ability of employees to make decision by the way team working (Koçel, 2010: 408409). In other words, it states conditions and implementations in that employee feel motivated, increased trust in their experience and knowledge, yearn to act by taking initiative, they can perform tasks that they accept meaningful. Empowerment is a motivational process for Conger and Kanungo (1988).

Thomas and Velthouse describe empowerment with parameters that construct the employee motivation (1990). They state empowerment as a cognitive process and based their empowerment model on four elements which are meaning, competence, choice, and impact. The concept of the empowerment should be defined clearly to not be confused with the concept of motivation, authorization and job enrichment. Although authority was given for certain period, empowerment is permanently. In other words, empowerment is permanent authority to make decision without asking to anybody.

Before the 1990s, the concept of the involvement was used frequently instead of the concept of the empowerment. But, empowerment has a larger meaning than involvement. The concept of empowerment contains concept of the involvement (Şimşek ve Kıngır, 2006: 99). The other concept which is confused with empowerment is job enrichment. Job enrichment especially focuses on the job and its characteristic, not on employee, but empowerment focus on employees and their cognition (Spreitzer, 1996: 484).

Thomas and Velthouse (1990) defined empowerment as instrinsic motivation that is comprised of four cognitions that reflect an individual's orientation to his or her work role. These four cognition are meaning, competence, self-determination and impact.

Meaning involves a fit between the requirements of a work role and employee beliefs, values and behaviors.

Competence refers to self -efficacy specific to work and a belief in one's capability to perform work activities with skill.

Self - determination refers to autonomy over the initiation and continuation of work behavior and process: making decisions work methods and pace and afford are examples.

Impact is the degree to which a person can influence strategic and administrative or operating outcomes at work. The lack of the one of them can cause a decrease in the impact of the empowerment. Empowerment is a process and focuses on human; therefore, its results can be seen in the long term (Y1ldırım, 2004: 27). Some variables are important to be successful in the empowerment process, which are organizational variables, managerial styles, awarding system and job design (Barutçugil, 2004: 402403).

The one of the most important variables to be successful in empowerment process is the organizational commitment. The commitment was defined by Harold Guetzkov (1955) as a behavior that makes people ready against to a groub, people and idea. Many commitment studies were carried out. The most accepted of them are following; Becker (1960), Etzioni (1961), Kanter (1968), Mowday, Steers and Porter (1979), O'Reilly and Chatman (1986) and Allen and Meyer (1990). Their classifications were used in the 
most studies related to the commitment. Allen and Meyer (1990, s.3) defined organizational commitment as a behavior that supports employees' decision to be permanent member of the organization. That behavior is shaped by the relationship of employees with organization. Organizational commitment is evaluated in three dimensions, which are emotional commitment, continual commitment and normative commitment. But Mowday, Steers and Porter (1979, s.225) evaluated organizational commitment in two dimensios as behavioral commitment and attitude commitment. There are many studies in literature such as K McDermott, HK Laschinger, J Shamian, (1996), HK Laschinger, J Finegan (2001), L Kuokkanen, H Leino-Kilpi, J Katajisto (2003), Sang-Sook Han, at all (2009), Sut I Wong Humborstad, Chad Perry (2011), Beom Cheol (Peter) Kim et al. (2012),Steffen Raub and Christopher Robert (2013). Those studies examine the different aspects and different relations between empowerment and organizational commitment. But there are not sufficient studies that examine the relationship between empowerment and commitment in hotel industry. Hotel establehments sre stated as manpowered business. Manpower plays a key role in providing competitive advantages and in creating customer satisfaction. Therefore, positive emotions and commitment in manpower agains their hotel must be developed. In this point, the relationship between empowerment and commitment should be examined.

\section{The Methotology of Study}

\section{Model and Hyphothesis of the Study}

Present study is an exploratory study. This study was carried out to examine the relationship between empowerment and organizational commitment and differentation of the relationship in terms of the some demographic variables. In this scope, the research model constructed as follow;

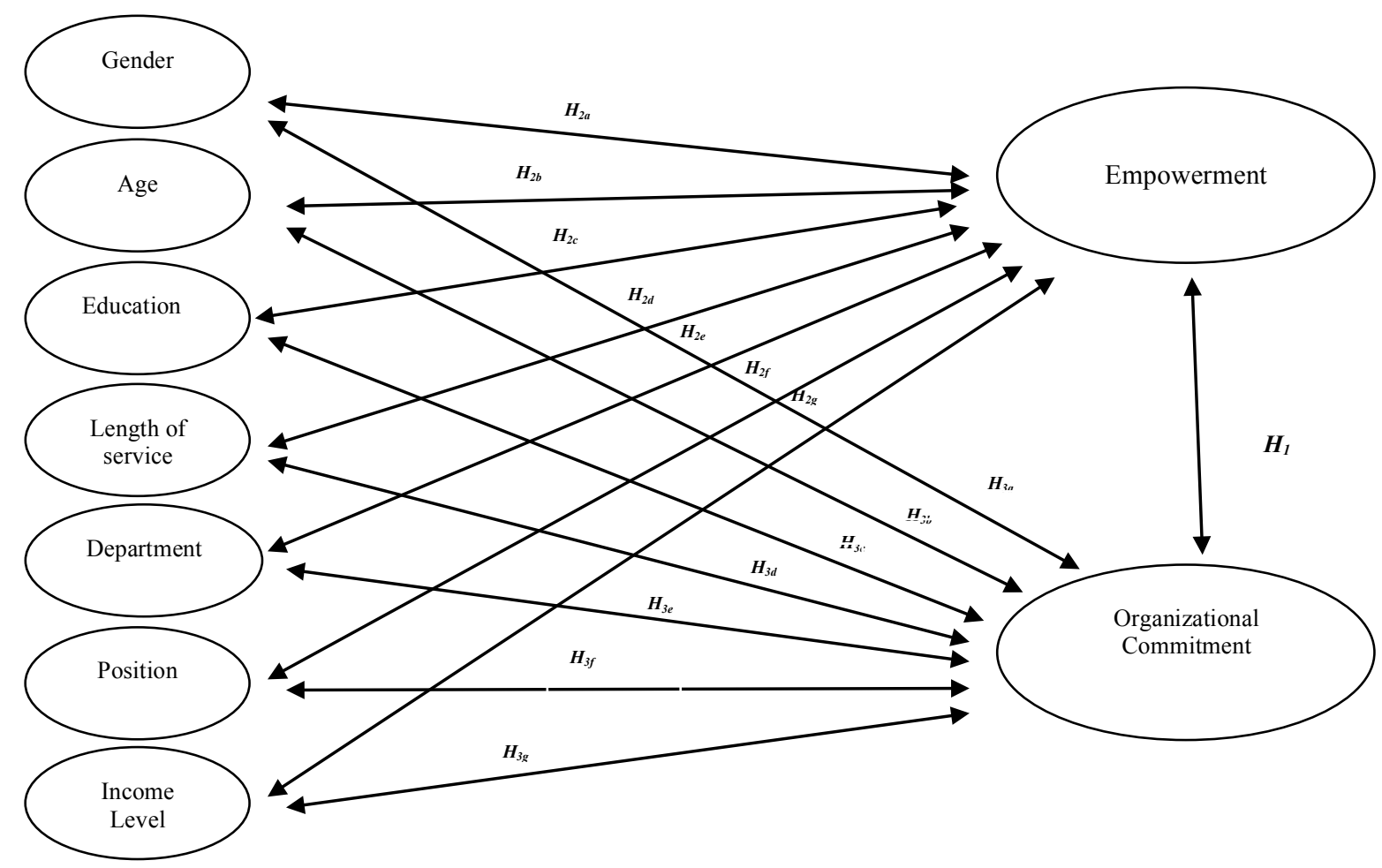


In the scope the model of the study the hypotheses were determined as following;

$H_{1}$ : There is a significant relationship between employees' empowerment perceptions and their organizational commitments.

$\mathrm{H}_{2}$ : Employees' empowerment perceptions differ significantly in terms of demographic variables.

$\mathrm{H}_{2 \mathrm{a}}$ : In terms of the gender variable employees' empowerment perceptions differ significantly.

$\mathrm{H}_{2 \mathrm{~b}}$ : In terms of the age variable employees' empowerment perceptions differ significantly

$\mathrm{H}_{2 \mathrm{c}}$ : In terms of the aducation level variable employees' empowerment perceptions differ significantly

$\mathrm{H}_{2 \mathrm{~d}}$ : In terms of the length of the service employees' empowerment perceptions differ significantly

$\mathrm{H}_{2 \mathrm{e}}$ : In terms of the department variable employees' empowerment perceptions differ significantly

$\mathrm{H}_{2 \mathrm{f}}$ : In terms of the position variable employees' empowerment perceptions differ significantly

$\mathrm{H}_{2 \mathrm{~g}}$ : In terms of the income level variable employees' empowerment perceptions differ significantly

\section{$\mathrm{H}_{3}$ : Employees' organizational commitments differ significantly in terms of some demographic variables.}

$\mathrm{H}_{3 \mathrm{a}}$ : In terms of the gender variable employees' organizational commitments differ significantly.

$\mathrm{H}_{3 \mathrm{~b}}$ : In terms of the age variable employees' organizational commitments differ significantly

$\mathrm{H}_{3 c}$ : In terms of the aducation level variable employees' organizational commitments differ significantly

$\mathrm{H}_{3 \mathrm{~d}}$ : In terms of the length of the service employees' organizational commitments differ significantly

$\mathrm{H}_{3 \mathrm{e}}$ : In terms of the department variable employees' organizational commitments differ significantly

$\mathrm{H}_{3 \mathrm{f}}$ : In terms of the position variable employees' organizational commitments differ significantly

$\mathrm{H}_{3 \mathrm{~g}}$ : In terms of the income level variable employees' organizational commitments differ significantly

\section{The Population and Sample of the Study}

The population of the study comprises 4216 employees of the 16 stars hotels in Ankara - Turkey. The sample groub was determined because of the difficulty to reach to all population. The sample size was determined by using Yamane's formula. According to the result of the calculation, the sample size was determined as 386 respondents. 464 questionnaires were prepared and equally (29) distributed to 16 hotels. 410 questionnaires were found appropriate for analyzing. 


\section{Data Collection and Analyzing}

A questionaire was used to collect data from respondends. The questionnaire was prepared in three sections. The first section includes questions which are related to demographic features of employees, the second section includes statements to determine empowerment perception of employees and the third section includes statements to measure commitment of employees. The questionnaires were filled by pollsters by face to face by interview technique. Questions were prepared in the form of the 5-point Likert scale. Empowerment and commitment scale were developed from Özbeks dissertation. The collected data was analyzed by using Pearson Correlation, $t$ test and ANOVA and regression analysis.

\section{Finding}

\section{Findings About Demographic Variables of Participants}

Descriptive statistics about employees were given table 1.

Table 1: The Descriptive statistics of participators employees

\begin{tabular}{|c|c|c|c|}
\hline Demographic Variables & & Frequency & Percentage \\
\hline \multirow{2}{*}{ Gender } & Female & 138 & 33.7 \\
\hline & Male & 272 & 66.3 \\
\hline \multirow{6}{*}{ Age } & $18-24$ & 54 & 13.2 \\
\hline & $25-31$ & 178 & 43.4 \\
\hline & $32-38$ & 97 & 23.7 \\
\hline & $39-45$ & 52 & 12.7 \\
\hline & 45 and over & 29 & 7.1 \\
\hline & Total & 410 & 100 \\
\hline \multirow{7}{*}{ Education Level } & Primary School & 4 & 1.0 \\
\hline & Secondary School & 34 & 8.3 \\
\hline & High School & 110 & 26.8 \\
\hline & College & 86 & 21.0 \\
\hline & Undergraduate & 146 & 35.6 \\
\hline & Graduate & 30 & 7.3 \\
\hline & Total & 410 & 100 \\
\hline \multirow{6}{*}{ Length of Service } & $1-5$ & 202 & 49.3 \\
\hline & $6-10$ & 98 & 23.9 \\
\hline & $11-15$ & 70 & 17.1 \\
\hline & $16-20$ & 20 & 4.9 \\
\hline & 21 and over & 20 & 4.9 \\
\hline & Total & 410 & 100 \\
\hline \multirow{5}{*}{ Departmant } & Front Office & 144 & 35.1 \\
\hline & Housekeeping & 50 & 12.2 \\
\hline & Food and Beverage & 140 & 34.1 \\
\hline & Other & 76 & 18.5 \\
\hline & Total & 410 & 100 \\
\hline \multirow{5}{*}{ Postion } & Worker & 281 & 68.5 \\
\hline & Lower Level Manager & 72 & 17.6 \\
\hline & Middle level Manager & 48 & 11.7 \\
\hline & Top Level Manager & 9 & 2.2 \\
\hline & Total & 410 & 100 \\
\hline \multirow{5}{*}{ Income Level } & 1000 and below & 100 & 24.4 \\
\hline & $1001-2000$ & 269 & 65.6 \\
\hline & $2001-3000$ & 35 & 8.5 \\
\hline & $3001-4000$ & 6 & 1.5 \\
\hline & Total & 410 & 100 \\
\hline
\end{tabular}


2. The Findings About the Relationship between Emploee Empowerment and Organizational Commitment

The Pearson correlation was used to determine the relationship between employee empowerment and organizational commitment. The Pearson correlation coefficient was given in Table 2. According to the Table 2, there is a significant relationship between employee empowerment and organizational commitment at significant level of 0.05 $(\mathrm{P}<0.01)$. In accordance with this result hypothesis of $\mathbf{H}_{\mathbf{1}}$ was accepted

The regression analysis was used to measure the effect of the employee empowerment over organizational commitment. The result of the regression analysis was given in Table 3. According to the table 3, $r^{2}$ was calculated as $r^{2}=, 248$. In other words, the effect of the empowerment over organizational commitment is $24.8 \%$. Also, the other variables have $75.2 \%$ effect over organizational commitment.

Table 2: the Relationship between Employees' Empowerment and Their Organizational Commitments

\begin{tabular}{|c|c|c|c|}
\hline & & $\begin{array}{l}\text { The Means of } \\
\text { the Employee } \\
\text { Empowerment }\end{array}$ & $\begin{array}{c}\text { The Means of } \\
\text { Organizational } \\
\text { Commitment } \\
\end{array}$ \\
\hline \multirow{3}{*}{$\begin{array}{l}\text { The Means of The } \\
\text { Employee Empowerment }\end{array}$} & Pearson Correlation & 1 & .498 \\
\hline & Sig. (2-tailed) & .000 & \\
\hline & $\mathrm{N}$ & 410 & \\
\hline
\end{tabular}

$* p<0.01$ Correlation is significant at the 0.01 level (2-tailed).

Table 3: the regression analysis of the Employee's Empowerment Perceptions and their Organizational Commitments

\begin{tabular}{lccl}
\hline Model & $\mathrm{R}$ & $\mathrm{R}^{2}$ & Adjusted $\mathrm{R}^{2}$ \\
\hline 1 &, $498^{\mathrm{a}}$ & 248 &, 246 \\
\hline
\end{tabular}

aPredictors: (Constant),

3. The Differentiation of the Employees' Empowerment Perceptions and Their Organizational Commitments in terms of Some Demographic Variables

The differentiation of the employees' empowerment perceptions and organizational commitments in terms of the gender variable was given in Table 4. At 0.05 significance level, Employees' empowerment perceptions and their organizational commitments do not differ signicantly $(p<0.05)$ in terms of the gender variables. Therefore, the hypothesis of $\mathrm{H}_{2 \mathrm{a}}$ and $\mathrm{H}_{3 \mathrm{a}}$ were not accepted.

Table 4: the Differentiation of the Employees' Empowerment Perceptions and Their Organizational Commitments In terms of Gender Variable

\begin{tabular}{lllllll}
\hline & Gender & $\mathbf{N}$ & $\bar{X}$ & $\mathbf{s . d .}$ & $\mathbf{t}$ & $\mathbf{p}$ \\
\hline Employees & Female & 138 & 3.8903 & .74140 & \multirow{2}{*}{$\mathbf{1 . 1 0 0}$} & \multirow{2}{*}{$\mathbf{2 7 2}$} \\
Empowerment & Male & 272 & 3.9713 & .68524 & & \multirow{2}{*}{$\mathbf{2 5 9}$} \\
\hline Organizational & Female & 138 & 3.2986 & .46147 & $\mathbf{2 0 . 1 7 7}$ & $\mathbf{. 8 5 9}$ \\
Commitment & Male & 272 & 3.3076 & .50142 &
\end{tabular}

The differentiation of the employees' empowerment perceptions and their organizational commitments in terms of the age variable was given in Table 5. At 0.05 
significance level, Employees' empowerment perception and organizational commitments differ signicantly $(\mathrm{p}<0.05)$ in terms of the age variables. Therefore, the hypothesis of $\mathrm{H}_{2 b}$ and $\mathrm{H}_{3 \mathrm{~b}}$ were accepted. In other words, workers' perceptions about empowerment and organizational commitment differ in accorndance with their education levels.

Table 5: the Differentiation of the Employees' Empowerment Perceptions and their Organizational Commitments in terms of the Age Variable

\begin{tabular}{lllllll}
\hline & Age & $\mathbf{N}$ & $\overline{\mathbf{X}}$ & $\mathbf{s . d .}$ & $\mathbf{F}$ & $\mathbf{p}$ \\
\hline \multirow{2}{*}{ Employee } & $18-24$ & 54 & 3.649 & 71898 & & \\
Empowerment & $25-31$ & 178 & 4.0281 & 73252 & & \\
& $32-38$ & 97 & 3.8021 & 71514 & $\mathbf{5 . 5 6 9}$ & $\mathbf{. 0 0 0}$ \\
& $39-45$ & 52 & 4.1346 & 52406 & & \\
\hline & 45 and over & 29 & 4.1103 & 20952 & & \\
Organizational & $18-24$ & 54 & 3.2444 & 46765 & & \\
Commitment & $25-31$ & 178 & 3.3727 & 45622 & & \\
& $32-38$ & 97 & 3.1952 & 53188 & $\mathbf{4 . 2 6 5}$ & $\mathbf{. 0 0 2}$ \\
& $39-45$ & 52 & 3.4346 & 53600 & & \\
\hline
\end{tabular}

${ }^{*} p<0.05$

The differentiation of the employees' empowerment perceptions and their organizational commitments in terms of the educational level variable was given table 6. At 0.05 significance level, Employee empowerment do not differ signicantly $(\mathrm{p}>0.05)$ in terms of the age variables. Therefore the hyphotesis of $\mathrm{H}_{2 \mathrm{c}}$ was not accepted. However, organizational commitment differs significantly $(\mathrm{p}<0.05)$ at 0.05 significance level in terms of the educational level variables. According to this result, the hyphotesis of $\mathrm{H}_{3 \mathrm{c}}$ was accepted. The perceptions about empowerment and organizational commitment of workers who graduated from primary school were higher than the other workers.

Table 6: the Differentiation of the Employees' Empowerment Perceptions and their Organizational Commitments in terms of the Education Level Variable

\begin{tabular}{lllcccc}
\hline & Education Level & \multicolumn{1}{c}{$\mathbf{N}$} & $\bar{X}$ & s.d. & \multicolumn{1}{c}{ F } & \multicolumn{1}{c}{ p } \\
\hline \multirow{3}{*}{ Employee Empowerment } & Primary School & 4 & 4.6000 & .46188 & & \\
& Secondary School & 34 & 3.9765 & .68340 & & \\
& High School & 110 & 3.8848 & .75359 & $\mathbf{1 . 9 7 0}$ & $\mathbf{. 0 8 2}$ \\
& College & 86 & 3.9690 & .72934 & & \\
& Under garduate & 146 & 3.8922 & .65625 & & \\
& Graduate & 30 & 4.2178 & .66181 & & \\
\hline \multirow{5}{*}{ Organizational } & Primary School & 4 & 3.7333 & .61584 & & \\
Commitment & Secondary School & 34 & 3.2585 & .43601 & & \\
& High School & 110 & 3.3079 & .44625 & $\mathbf{3 . 9 1 3}$ & $\mathbf{. 0 0 2}$ \\
& College & 86 & 3.3752 & .43973 & & \\
& Under garduate & 146 & 3.2078 & .52979 & & \\
\hline & Graduate & 30 & 3.5556 & .47604 & & \\
\hline
\end{tabular}

${ }^{*} p<0.05$

The differentiation of the employees' empowerment perceptions and their organizational commitments in terms of the length of service variable was given in Table 7. At 0.05 significance level Employee empowerment are do not differ significantly $(\mathrm{p}<0.05)$ in terms of the length of service variable. Therefore the hyphotesis of $\mathbf{H}_{\mathbf{2 d}}$ was not accepted. However, organizational commitment differ significantly 
$(p<0.05)$ at 0.05 significance level in terms of the working year variable. According to this result, the hyphotesis of $\mathbf{H}_{\mathbf{3 d}}$ was accepted. The perceptions of empowerment and organizational commitment of the workers who worked 21 years and over were higher than the other workers.

Table 7: the Differentiation of the Employees' Empowerment Perceptions and their Organizational Commitments in terms of Length of Service Variable

\begin{tabular}{lllllll}
\hline & Lenght of service & $\mathbf{N}$ & $\bar{X}$ & s.d. & F & p \\
\hline \multirow{2}{*}{ Employee Empowerment } & $1-5$ & 202 & 3.8739 & .78614 & & \\
& $6-10$ & 98 & 4.0265 & .71775 & & \\
& $11-15$ & 70 & 3.9419 & .48340 & $\mathbf{1 0 0}$ & $\mathbf{. 0 8 0}$ \\
& $16-20$ & 20 & 3.9067 & .59644 & & \\
& 21 and over & 20 & 4.2933 & .32038 & & \\
Organizational & $1-5$ & 202 & 3.3419 & .44809 & & \\
Commitment & $6-10$ & 98 & 3.3252 & .60855 & & \\
& $11-15$ & 70 & 3.1219 & .44843 & $\mathbf{3 . 7 1 8}$ & $\mathbf{. 0 0 6}$ \\
$*_{p<0.05}$ & $16-20$ & 20 & 3.2700 & .34163 & & \\
& 21 and over & 20 & 3.5000 & .28077 & & \\
\end{tabular}

The differentiation of the employees' empowerment perceptions and their organizational commitments in terms of the deparment variable was given in Table 8 . At 0,05 significance level Employee empowerment are do not differ significantly $(p<0.05)$ in terms of the department variable. Therefore, the hyphotesis of $\mathbf{H}_{2 \mathbf{e}}$ was not accepted. However, organizational commitment differ significantly $(p<0.05)$ at 0.05 significance level in terms of the department variable. According to this result, the hyphotesis of $\mathbf{H}_{3 \mathbf{e}}$ was accepted. The front office employee's empowerment perception is higher than tother departments's employees. In same way, house keeping employee's organizational commitment perceptions is higher than others.

Table 8: the Differentiation of the Employees' Empowerment Perceptions and their Organizational Commitments In terms of Department Variable

\begin{tabular}{lllcccc}
\hline & Department & $\mathbf{N}$ & $\bar{X}$ & s.d & F & p \\
\hline \multirow{2}{*}{ Employee Empowerment } & Front Office & 144 & 4.0056 & .61165 & & \\
& House Keeping & 50 & 3.9267 & .92044 & $\mathbf{2 . 1 6 3}$ & $\mathbf{. 0 9 2}$ \\
& Food and Beverage & 140 & 3.9838 & .61549 & & \\
& Other & 76 & 3.7658 & .83498 & & \\
\hline \multirow{3}{*}{ Organizational Commitment } & Front Office & 144 & 3.3903 & .50032 & & \\
& House Keeping & 50 & 3.4720 & .31582 & $\mathbf{1 0 . 6 8 4}$ & $\mathbf{. 0 0 0}$ \\
& Food and Beverage & 140 & 3.1267 & .46569 & & \\
& Other & 76 & 3.3596 & .50819 & & \\
\hline
\end{tabular}

${ }^{*} p<0.05$

The differentiation of the employees' empowerment perceptions and their organizational commitments in terms of the position variable was given in Table 9. At 0.05 significance level, Employee empowerment and organizational commitment differ significantly $(p<0.05)$ in terms of the postion variables. Therefore, the hypothesis of $\mathbf{H}_{\mathbf{2 f}}$ and $\mathbf{H}_{\mathbf{3 f}}$ were accepted. In other words, employees' perceptions about empowerment and organizational commitments differ according to their position. The workers' empowerment perceptions are higher than managers'. In the same way, lower level managers' organizational commitment perceptions are higher than others. 
Table 9: the Differentiation of the Employees' Empowerment Perceptions and their Organizational Commitments in terms of Position Variable

\begin{tabular}{lllllll}
\hline & Position & N & s.d. & $\bar{X}$ & F & p \\
\hline \multirow{3}{*}{ Employee Empowerment } & Worker & 281 & .75571 & 3.8633 & \multirow{2}{*}{} & \multirow{2}{*}{. } \\
& Lower Level M. & 72 & .38743 & 4.1417 & $\mathbf{7 . 9 3 2}$ & $\mathbf{. 0 0 0}$ \\
& Middle level M. & 48 & .67003 & 3.9597 & & \\
& Top Level M. & 9 & .17321 & 4.8000 & & \\
\hline & Worker & 281 & .47532 & 3.2574 & & \\
\multirow{3}{*}{ Organizational Commitment } & Lower Level M. & 72 & .50814 & 3.3583 & $\mathbf{4 . 7 4 7}$ & $\mathbf{. 0 0 3}$ \\
& Middle level M. & 48 & .49945 & 3.4139 & & \\
& Top Level M. & 9 & .29648 & 3.7630 & & \\
\hline
\end{tabular}

${ }^{*} p<0.05$

The differentiation of the employees' empowerment perceptions and their organizational commitments in terms of the income level variable was given in Table 10. At 0.05 significance level, the employees' empowerment and their organizational commitments differ signicantly $(p<0.05)$ in terms of the income level variable. Therefore, the hypothesis of $\mathbf{H}_{\mathbf{2 g}}$ and $\mathbf{H}_{\mathbf{8 g}}$ were accepted. In other words employees' perceptions about empowerment and organizational commitments differ according to their income level. The workers with 2001-3000 TL income level, empowerment perception is higher than other income level. In terms of organizational commitment, the workers with 3001-4000 TL income level, organizational commitment perception is higher than the others.

Table 10: the Differentiation of the Employees' Empowerment Perceptions and their Organizational Commitments in terms of in come Variable

\begin{tabular}{lllllll}
\hline & Income Level & $\mathbf{N}$ & $\bar{X}$ & s.d. & F & p \\
\hline Employee & 1000 and less & 100 & 3.7747 & .79718 & & \\
Empowerment & $1001-2000$ & 269 & 3.9722 & .68955 & & \\
& $2001-3000$ & 35 & 4.1848 & .46162 & $\mathbf{3 . 5 9 5}$ & $\mathbf{0 . 0 1 4}$ \\
& $3001-4000$ & 6 & 4.1000 & .24855 & & \\
\hline & 1000 and less & 100 & 3.2073 & .51325 & & \\
Organizational & $1001-2000$ & 269 & 3.3152 & .46205 & & \\
Commitment & $2001-3000$ & 35 & 3.4362 & .44761 & $\mathbf{3 . 4 4 8}$ & $\mathbf{0 . 0 1 7}$ \\
\hline & $3001-4000$ & 6 & 3.6778 & .97927 & & \\
\hline
\end{tabular}

${ }^{*} p<0.05$

\section{Conclusion and Remarks}

According to the results of the statistical analy, there is a significant relationship $(r=498)$ between employees' empowerment perceptions and organizational commitment. Therefore, hyhothesis $\mathrm{H}_{1}$ was accepted. Also, the effect of the employee empowerment over organizational commitment was analyzed by regreation test. It was found that empowerment has $0,248 \%$ effect over organizational commitment.

Mean while the differentiation of the empowerment perception and organizational commitment of employees by some demographic variables were examined. At this stage, It is find out that empowerment perceptions of the employees are differ significantly in terms of the education level, postion in organization, income 
level variables. But it did not differ in terms of the gender, age, lenght of service and department variables.

On the subject of organizational commitment of employees, there is no significant differentiation in terms of the gender variable. However, there are significant differentiation in terms of the the education level, postion in organization, income level, age, lenght of service and department variables

As a result, there is a significant relation between empowerment and organizational commitment. Also, empowerment affects organizational commitment level of the employees. Its effect level was calculated as $24.8 \%$, which is important. Who wants to improve organizational commitment level of their employees should take empowerment concept into consideration to be successful. Also, differentiation of the empowerment perception and organizational commitments of the employees in terms of the demographic variables should be taken into consideration by the managers to determine the alternatives to build high performanced organization atmosphere.

\section{Resources}

Allen, N. J., \& Meyer, J. P. (1990). The measurement and antecedents of affective, continuance and normative commitment to the organization. Journal of occupational psychology, 63(1), 1-18.

Barutçugil, İ. (2004). Stratejik insan kaynakları yönetimi. (1. basım) İstanbul: Kariyer Yayınlar1.

Becker, H., (1960). "Notes on the Concept of Commitment", The American Journal of Sociology, Vol.66, No.1, s.32-40.

Conger, J. A., \& Kanungo, R. N. (1988). The empowerment process: Integrating theory and practice. Academy of management review, 13(3), 471-482.

Doğan, S. (2003). Personel güçlendirme. İstanbul: Sistem Yayıncılık.

Etzioni, A. (1961). Complex organizations: A sociological reader. New York: Holt, Rinehart and Winston.

Guetzkow, H. (1955). Multiple loyalties. Publication, 4.

Han, S. S., Moon, S. J., \& Yun, E. K. (2009). Empowerment, job satisfaction, and organizational commitment: comparison of permanent and temporary nurses in Korea. Applied Nursing Research, 22(4), e15-e20..

Kim, B. P., Lee, G., Murrmann, S. K., \& George, T. R. (2012). Motivational Effects of Empowerment on Employees' Organizational Commitment A Mediating Role of Management Trustworthiness. Cornell Hospitality Quarterly,53(1), 10-19.

Kanter, R.M., (1968). "Commitment and Social Organizations: A Study of Commitment Mechanisms in Utopian Communities", American Sociological Review, Vol.33, No.4, s.499-516.

Koçel T. (2010) Işsletme Yöneticiliği Yönetim Ve Organizasyon Organizasyonlarda Davranış Klasik-Modern-Çağdaş Ve Güncel Yaklaşımlar. (12. Baskı). İstanbul:Beta Basım Yayım.

Kuokkanen, L., Leino-Kilpi, H., \& Katajisto, J. (2003). Nurse empowerment, jobrelated satisfaction, and organizational commitment. Journal of Nursing Care Quality, 18(3), 184-192. 
Laschinger, H. K. S., Finegan, J., \& Shamian, J. (2001). The impact of workplace empowerment, organizational trust on staff nurses' work satisfaction and organizational commitment. Health Care Management Review, 26(3), 7-23.

McDermott K, Laschinger HK, Shamian J. (1996) Work empowerment and organizational commitment. Nuring Manage. May;27(5):44-47

Mowday, R. T., Steers, R. M., \& Porter, L. W. (1979). The measurement of organizational commitment. Journal of vocational behavior, 14(2), 224-247.

O'Reilly, C. A., \& Chatman, J. (1986). Organizational commitment and psychological attachment: The effects of compliance, identification, and internalization on prosocial behavior. Journal of applied psychology, 71(3), 492.

Raub S., Robert C. (2013) Empowerment, Organizational Commitment, and Voice Behavior in the Hospitality Industry.Cornell Hospitality Quarterly May 2013vol. 54 no. 2 136-148

Spreitzer, G. M. (1995). Psychological empowerment in the workplace: Dimensions, measurement, and validation. Academy of management Journal,38(5), 14421465.

Şimşek, M. Ş. ve Kıngır, S. (2006) Çağdaş yönetim araçlarından seçmeler. Ankara: Nobel Yayın Dağıtım

Thomas, K. W., \& Velthouse, B. A. (1990). Cognitive elements of empowerment: An "interpretive" model of intrinsic task motivation. Academy of management review, 15(4), 666-681.

Yıldırım, H. (2004). Personel Güçlendirme: Çağdaş Yönetim Yaklaşımları Illkeler, Kavramlar ve Yaklaşımlar. Editör: İsmail Bakan İstanbul: Beta Basım Yayım 